\title{
Changes in enzymatic activity during early development of bay scallops Argopecten irradians and sea scallops Placopecten magellanicus
}

\author{
Lisa M. Milke ${ }^{1, *}$, V. Monica Bricelj ${ }^{2}$, Neil W. $\operatorname{Ross}^{3,4}$ \\ ${ }^{1}$ NOAA National Marine Fisheries Service, Milford Laboratory, Milford, Connecticut 06460, USA \\ ${ }^{2}$ Institute of Marine and Coastal Sciences, Rutgers University, New Brunswick, New Jersey 08901, USA \\ ${ }^{3}$ Institute for Marine Biosciences, National Research Council of Canada, Halifax, Nova Scotia B3H 3Z1, Canada \\ ${ }^{4}$ Present address: Industrial Research Assistance Program, National Research Council of Canada, Halifax, \\ Nova Scotia B3H 3Z1, Canada
}

\begin{abstract}
Poor growth and survival of scallops is often reported during early developmental stages. Stage- and species-specific dietary requirements have been identified, but the mechanisms responsible for these differences remain largely unknown. Dietary success depends on food biochemical properties, digestive and/or assimilative capacity, as well as the animal's specific nutritional demands, which can vary over development and between species. The present study examines developmental changes in the activities of key digestive enzymes in larval and postlarval bay scallops Argopecten irradians and sea scallops Placopecten magellanicus raised on a mixed algal diet until 4 to $5 \mathrm{~mm}$ in shell height (SH) and sampled at intervals encompassing major transitions in feeding organ development. Colorimetric assays measured general protease, lipase (esterase) and carbohydrase ( $\alpha$-amylase, cellulase and laminarinase) activities. The most pronounced changes in enzymatic activity occurred prior to scallops attaining $\sim 1.2 \mathrm{~mm}$ SH in both scallop species. The esterase:protease ratio exhibited similar ontogenetic patterns in both scallop species, decreasing sharply between larval and immediate postlarval stages before increasing to an intermediate level and stabilizing around $1.2 \mathrm{~mm} \mathrm{SH}$. In contrast, mean carbohydrase activities measured over the experimental duration differed between species, with bay scallops exhibiting higher specific activities of $\alpha$-amylase and cellulase but much lower activities of laminarinase than sea scallops. These findings have implications for understanding scallop utilization of the food supply in nature, as well as developing targeted diets that could enhance their growth and survival in culture.
\end{abstract}

KEY WORDS: Digestive enzyme activity $\cdot$ Scallops $\cdot$ Placopecten magellanicus $\cdot$ Argopecten irradians · Development

Resale or republication not permitted without written consent of the publisher

\section{INTRODUCTION}

Larval and early-postlarval development of bivalves is marked by pronounced changes in behavior, physiology, habitat and morphogenesis of feeding organs (Sastry 1965, Beninger et al. 1994, Kennedy 1996, Barré 2001, Chaparro et al. 2001, Veniot et al. 2003). Stage- and species-specific differences in dietary needs have been identified for different bivalve species, including the scallop Argopecten purpuratus
(Uriarte \& Farias 1999 and references therein, Milke et al. 2006), although the mechanisms responsible for these requirements are not fully understood. While biochemical composition of the diet is undoubtedly important, the ability to digest and assimilate various substrates is also necessary to ensure optimal growth and survival. Digestive capacity may develop in parallel with morphogenesis of feeding organs, and the activities of various digestive enzymes may influence dietary success. 
Digestive capacity may also differ between species with differing life histories or environmental adaptations (Albentosa \& Moyano 2009). The sea scallop Placopecten magellanicus is restricted to cold waters $\left(\leq 20^{\circ} \mathrm{C} ; \mathrm{Naidu} 1991\right)$ and growth rates are relatively slow, attaining a market size of $90 \mathrm{~mm}$ shell height (SH) in 3 yr (Dadswell \& Parsons 1991). The northern bay scallop Argopecten irradians irradians is a temperate subspecies with natural populations occurring in subtidal estuarine environments (Couturier et al. 1995). They are generally restricted to waters $<10 \mathrm{~m}$ in depth, and grow much faster than sea scallops. Bay scallops are capable of attaining market size $(50 \mathrm{~mm} \mathrm{SH})$ in a single growing season (Rhodes \& Widman 1980).

A number of studies have determined the activity of digestive enzymes of adult bivalves including bay scallops (Brock et al. 1986) and sea scallops (Wojtowicz 1972), and a few studies have focused on the digestive enzymes of larval and juvenile bivalves (Samain et al. 1995, Økland et al. 2001, Hoehne-Reitan et al. 2007, Albentosa \& Moyano 2008). Prior studies examining ontogenetic changes in digestive enzymes have been conducted on abalone (Takami et al. 1998), teleosts (Gawlicka et al. 2000, Pérez-Casanova et al. 2004, Jun-sheng et al. 2006) and crustaceans (Kamarudin et al. 1994, Ribeiro \& Jones 2000). Studies on ontogenetic digestive changes in bivalves, or that compare discrete life history stages, are limited to those conducted on Crassostrea gigas (LunaGonzález et al. 2004) and Pecten maximus (Økland et al. 2001, Reitan 2011).

The objectives of the present study were to (1) identify changes in digestive capacity measured by in vitro activity of digestive enzymes during early scallop development and (2) compare activities of key enzymes between Argopecten irradians and Placopecten magellanicus. This information could assist in the development of targeted diets for implementation in a commercial setting and may also increase understanding of bivalve-seston interactions in the natural environment.

\section{MATERIALS AND METHODS}

\section{Experimental animals}

Larval bay scallops Argopecten irradians were obtained from Lunenburg Shellfish Inc., Nova Scotia (NS), Canada, and transferred to the National Research Council's Marine Research Station (MRS), Ketch Harbour, NS, where they were held on a mixed diet (30 cells $\mathrm{\mu l}^{-1} ; 50 \%: 50 \%$ by volume) of Pavlova sp. (Center for the Culture of Marine Phytoplankton [CCMP] Strain 459)/Chaetoceros muelleri (CHGRA) at $20^{\circ} \mathrm{C}$ for $4 \mathrm{~d}$ prior to initial sampling at the pediveliger stage. Post-metamorphic bay scallops from the same cohort were received $10 \mathrm{~d}$ later and treated as above. Due to high mortalities after Day 11, the initial cohort of bay scallops (Cohort 1) was replaced on Day 19 by a second, 7 d younger cohort (Cohort 2, initial $\mathrm{SH}=700 \mu \mathrm{m}$ ) originating from the same broodstock. No sampling was conducted during the period of mortality in Cohort 1, and Cohort 2 was acclimated to the experimental diet for $6 \mathrm{~d}$ prior to sampling. Sea scallop Placopecten magellanicus larvae were spawned and reared at MRS and held on a diet of Pavlova pinguis/CHGRA at $14^{\circ} \mathrm{C}$ for $3 \mathrm{~d}$ prior to initial sampling. At this point sea scallops were sieved into 3 different size classes. Larvae and the smallest early postlarvae (526 $\mu \mathrm{m} \mathrm{SH})$ were sampled, and remaining sea scallops were used for subsequent postmetamorphic samplings.

\section{Experimental systems}

Larval scallops were held in aerated, $0.22 \mu \mathrm{m}$ filtered seawater on a mixed algal diet in 601 (bay scallop) or 7001 (sea scallop) tanks prior to initial sampling; larvae were sampled only once. For postlarval experiments, approximately 200000 bay scallops (initial $\mathrm{SH}=310 \mu \mathrm{m}$ ) and 120000 sea scallops (initial $\mathrm{SH}=$ $773 \mu \mathrm{m}$ ) were divided equally among 4 downwellers, 2 per each duplicate 4001 (bay scallops; $125 \mu \mathrm{m}$ initial mesh size) or 7001 (sea scallops; $130 \mu \mathrm{m}$ initial mesh size) recirculating seawater system. Downweller mesh sizes were increased commensurate with shell growth; bay and sea scallops reached a maximum of 1180 and $1000 \mu \mathrm{m} \mathrm{SH}$, respectively. Each scallop species was grown at its optimum temperature, i.e. 20 and $14^{\circ} \mathrm{C}$ for bay and sea scallops, respectively.

Microalgal stock cultures were obtained from the CCMP, West Boothbay Harbor, Maine, USA, and consisted of Pavlova sp. (CCMP 459; Pav 459), Pavlova pinguis (CCMP 609) and Chaetoceros muelleri (CCMP 1316; CHGRA). CHGRA and Pav 459 were grown in batch culture in $20 \mathrm{l}$ carboys at $20^{\circ} \mathrm{C}$, while $P$. pinguis was grown in semi-continuous culture in a 2001 photobioreactor at $21^{\circ} \mathrm{C}$ (the irradiance delivered to the culture volume inside the photobioreactor was $350 \mu \mathrm{mol} \mathrm{m} \mathrm{m}^{-2} \mathrm{~s}^{-1}$, as determined at the surface of the Pyrex sleeve surrounding each lamp). All species were grown with 24 h light, on f/2 ( without silica Si for flagellates; Guillard 1975) with supplemental $\mathrm{CO}_{2}$ and were harvested during the late exponential growth phase. 
Scallops were fed a binary diet of either Pav 459 or Pavlova pinguis in combination with CHGRA for $47 \mathrm{~d}$ (bay scallop) or $65 \mathrm{~d}$ (sea scallop) at $2.16 \times 10^{6} \mu^{3}$ $\mathrm{ml}^{-1}$; equivalent in biovolume to 50 cells $\mathrm{\mu l}^{-1}$ of Isochrysis galbana Strain T-iso. A diet of Pav 459 in combination with CHGRA, at this concentration, has resulted in high growth rates in postlarval bay and sea scallops (Milke et al. 2004, 2006). P. pinguis and Pav 459 are comparable in size and biochemical composition and have supported comparable growth rates in postlarval sea scallops when used in combination with CHGRA (Milke et al. 2008), so it was assumed that they could be interchanged without effect. Each algal species contributed to the diet equally by volume, and cell concentrations were monitored with a Multisizer 3 Coulter Counter (Beckman Coulter). Diets were maintained within $\leq 20 \%$ of the target concentration by daily batch additions and drip supplementation via peristaltic pump (Cole Parmer Masterflex 7554-80) when necessary.

\section{Scallop growth and survival}

Growth and survival was measured weekly via image analysis. Video of scallops from each downweller was taken using a Pulnix TMC7-DSP camera coupled with a dissecting scope (or lens for larger animals) and recorded on a Sony DVCAM (DSR-V10). Shell height determinations (umbo to distal shell edge for postlarvae; shell length was measured in larvae) were conducted by measuring 30 (bay scallop) or 50 (sea scallop) live scallops per downweller using Optimas 6.5 image analysis software (Media Cybernetics). For mortality estimates, in a sample 100 scallops per downweller were counted as live, 'new' dead and 'old' dead, converted to percent data, and then averaged to obtain tank and overall mortality for each sampling date. 'New' dead scallops were similar in size to live animals but showed no movement and/or partial tissue degradation, while 'old' dead scallops were smaller, they showed no movement but evidence of substantial or complete degradation of tissues.

\section{Enzymatic assays}

Seven to 9 samplings were conducted over time for analysis of enzyme activities up to a maximum size of 3.9 and $4.9 \mathrm{~mm} \mathrm{SH}$ in bay and sea scallops, respectively. For each sampling, a subset of scallops was removed from each downweller and placed in filtered seawater $(0.22$ or $1 \mu \mathrm{m})$ overnight to clear gut contents and to ensure that enzymatic measurements were not influenced by the presence of microalgae; preliminary experiments were unable to detect statistically significant effects of this brief starvation period on enzymatic activity $(p=0.10,0.75,0.21$ and 0.20 for esterase, protease, $\alpha$-amylase and laminarinase, respectively) except marginally for cellulase ( $p=0.046)$. The number of scallops in each sample was recorded, pooled whole scallops (including shell) were placed into cryovials, and samples were frozen in liquid $\mathrm{N}_{2}$ after removal of excess water. Samples were stored at $-80^{\circ} \mathrm{C}$ until analysis. Two tanks were sampled at each size, and 2 downwellers per tank, which yielded 2 discrete enzyme samples per tank. Downweller values were averaged to provide 1 tank value; therefore, values are more robust than is indicated by our sampling size of $\mathrm{n}=2$ for statistical analysis.

All samples were lyophilized and subsequently homogenized using a Polytron homogenizer, or by hand using a Teflon-coated rod for smaller samples, in $100 \mathrm{mM}$ ammonium bicarbonate buffer, $\mathrm{pH} 7.8$ (1 $\mathrm{g}$ tissue wet weight:5 $\mathrm{ml}$ buffer) on ice in order to minimize proteolytic degradation. Samples were centrifuged at $1700 \mathrm{~g}$ at $4^{\circ} \mathrm{C}$ for $10 \mathrm{~min}$, aliquoted into $0.5 \mathrm{ml}$ centrifuge tubes and stored at $-80^{\circ} \mathrm{C}$. Before analyses, samples were thawed on ice and again centrifuged at $5100 \mathrm{~g}$ at $4^{\circ} \mathrm{C}$ for $2 \mathrm{~min}$; only supernatant was used in assays. All protein concentration and enzymatic activities were determined colorimetrically on a SpectraMax Plus or VMax 96-well microplate reader (Molecular Devices) and analyzed using SoftMax Pro software Version 4.7.1 (Molecular Devices). Soluble protein was determined using a modified Lowry protocol (Bio-Rad; Lowry et al. 1951) using bovine serum albumin as standard and detection at $650 \mathrm{~nm}$. Preliminary trials determined the optimum incubation time and $\mathrm{pH}$ for each enzyme assay; all analyses were conducted at $30^{\circ} \mathrm{C}$, allowing for direct comparisons between different enzymes and scallop species. This temperature was chosen as it was within the range of temperature optima for carbohydrases in bay scallops $\left(28\right.$ to $32^{\circ} \mathrm{C}$; Brock et al. 1986), and following work on Placopecten magellanicus digestive enzymes by Wojtowicz (1972), who used $37^{\circ} \mathrm{C}$ for laminarinase, $25^{\circ} \mathrm{C}$ for amylase and $30^{\circ} \mathrm{C}$ for most other carbohydrases. Maximum individual enzymatic activities in ectotherms are typically attained at higher temperatures than the organism's upper environmental tolerance range (Le Chevalier et al. 1995, Pörtner 2002). Specific activities of 5 different enzymes were determined in the present study. 
Protease activity was determined using the azocasein hydrolysis assay (Charney \& Tomarelli 1947) modified by Ross et al. (2000) for microplate analysis. Homogenate was incubated with azocasein (Sigma A2765; final concentration of $3.5 \mathrm{mg} \mathrm{ml}^{-1}$ dissolved in $100 \mathrm{mM}$ ammonium bicarbonate buffer; $\mathrm{pH}$ 7.8) for $19 \mathrm{~h}$ on a rotator at $60 \mathrm{rpm}$. The reaction was stopped with the addition of $20 \%$ trichloroacetic acid (final concentration of $4.5 \%$ ); samples were cooled on ice and tubes were centrifuged at $17000 \mathrm{~g}$ for $5 \mathrm{~min}$, after which equal volumes of homogenate and $0.5 \mathrm{M}$ $\mathrm{NaOH}$ were added to microplate wells. Optical density was measured at $450 \mathrm{~nm}$, and $1 \mathrm{U}$ of activity was defined as the change in optical density per hour.

For determination of esterase activity, the homogenate was incubated with $0.4 \mathrm{mM}$ p-nitrophenyl myristate (Sigma; Huggins \& Lapides 1947) in $100 \mathrm{mM}$ ammonium bicarbonate buffer $(\mathrm{pH}$ 7.8) with $0.5 \%$ Triton $\mathrm{X}-100$. Change in optical density was monitored continuously for $1 \mathrm{~h}$ at $405 \mathrm{~nm}$, and $1 \mathrm{U}$ of activity was defined as $1 \mu \mathrm{mol}$ of p-nitrophenol liberated $\mathrm{min}^{-1}$ at $30^{\circ} \mathrm{C}$. The extinction coefficient of p-nitrophenol in microplate wells was determined empirically.

A p-hydroxybenzoic acid hydrazide (PAHBAH)reducing sugar assay was adopted for carbohydrase assays (Lever et al. 1973, Lever 1977), where an initial sample (allowing for no incubation time of substrate and tissue homogenate) was adopted as the sample blank and $1 \mathrm{mg} \mathrm{ml}^{-1} \mathrm{D}$-glucose (AnalaR) was used as standard. Briefly, substrate, buffer, $\mathrm{H}_{2} \mathrm{O}$ and tissue homogenate were added to $1.6 \mathrm{ml}$ centrifuge tubes and incubated at $30^{\circ} \mathrm{C}$ for $30 \mathrm{~min}$, after which the 4-hydrozybenzoic acid hydrazide (PAHBAH) reagent was added to stop the reaction. Samples were heated at $70^{\circ} \mathrm{C}$ for $10 \mathrm{~min}$ to facilitate color development. After cooling, samples were added to microplate wells, and optical density was read at $405 \mathrm{~nm}$. Final substrate and buffer concentrations, prior to PAHBAH addition, were as follows: $\alpha$-amylase, $0.5 \%$ soluble starch (Sigma, S-2630) and $0.08 \mathrm{M}$ sodium citrate buffer $\mathrm{pH} 6.5$; cellulase, $1 \%$ carboxymethyl cellulose (Sigma C-5678) and 0.05 M phosphate buffer pH 6.0; laminarinase, 0.2\% laminarin (Sigma L-9634) and 0.08 M sodium citrate buffer $\mathrm{pH}$ 5.5. Substrate concentrations were based on previous studies of marine organisms (Gawlicka et al. 2000, Fernández-Reiriz et al. 2005). Due to the high activity of laminarinase in the samples, tissue homogenates were diluted 1:1 with buffer prior to incubation. The assay measured the release of glucose-reducing group equivalents, and $1 \mathrm{U}$ of activity was defined as the release of $1 \mu \mathrm{mol}$ of glucose $\mathrm{min}^{-1}$ at $30^{\circ} \mathrm{C}$.

\section{Statistical analysis}

Scallops were divided into 3 distinct morphological stages: (1) larvae, (2) early postlarvae $<1 \mathrm{~mm} \mathrm{SH}$ and (3) late postlarvae $>1 \mathrm{~mm} \mathrm{SH}$. These were selected based on the known occurrence of major developmental changes in the functional morphology of the feeding organs, especially the gills, in the 2 scallop species (Barré 2001, Veniot et al. 2003). One-way ANOVAs were conducted to determine differences among these morphological stages for each scallop species and digestive enzyme. When significant differences were identified, pairwise multiple comparisons were conducted using the Holm-Sidak method (SigmaPlot 11.2, Systat Software). In the few cases when assumptions of normality and equal variance were not met, a Kruskal-Wallis 1-way ANOVA on ranks was conducted, followed by a Dunn's method pairwise multiple comparison test when appropriate. $T$-tests were conducted to examine species-specific differences for each digestive enzyme, combining all shell heights; a Mann-Whitney rank sum test was conducted in 2 cases when the assumptions of a $t$-test were not met. Analyses were conducted on SigmaPlot 11.0; the $\alpha$-level was chosen as $\mathrm{p}<0.05$.

\section{RESULTS}

\section{Scallop growth and mortality}

Growth of scallops fed the Pavlova spp./CHGRA diets throughout the experiment (Fig. 1) was best described by exponential equations and yielded predicted mean daily growth rates of 157 and $107 \mu \mathrm{m} \mathrm{d}^{-1}$ for bay and sea scallops, respectively. Total mortalities of bay scallop Cohort 1 were fairly low ( 15\%) during the first $11 \mathrm{~d}$ of the experiment, when sampling for enzymatic analysis was conducted. Scallops from Cohort 2 exhibited $76 \%$ survival by the end of the experiment at Day 47. Exceptionally low mortalities were observed during the sea scallop trial, with a final survivorship of $95 \%$ at Day 65.

\section{Enzymatic activity during development}

Soluble protein concentrations were variable over development, and ranged from 35.8 to 87.6 and 24.0 to $93.4 \mathrm{mg} \mathrm{g}^{-1} \mathrm{DW}$ for bay and sea scallops, respectively, with a reduction in values obtained immediately following metamorphosis in both species (Fig. 2). The specific activity of esterase was signifi- 


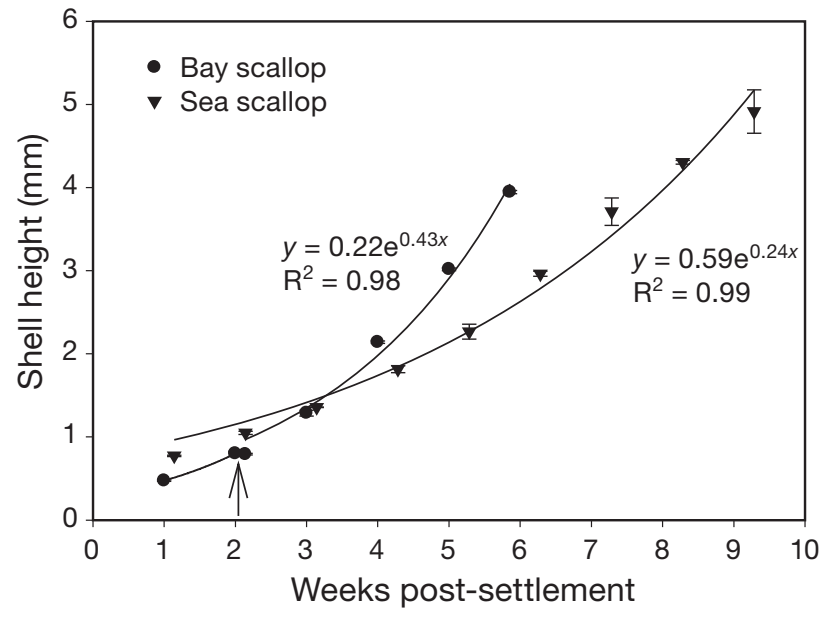

Fig. 1. Argopecten irradians, Placopecten magellanicus. Postmetamorphic shell growth trajectories of bay scallops $A$. irradians and sea scallops $P$. magellanicus. Values represent mean shell height $( \pm \mathrm{SE})$; arrow indicates size at which the initial bay scallop cohort was replaced with a second batch of animals (see 'Materials and methods: Experimental animals')

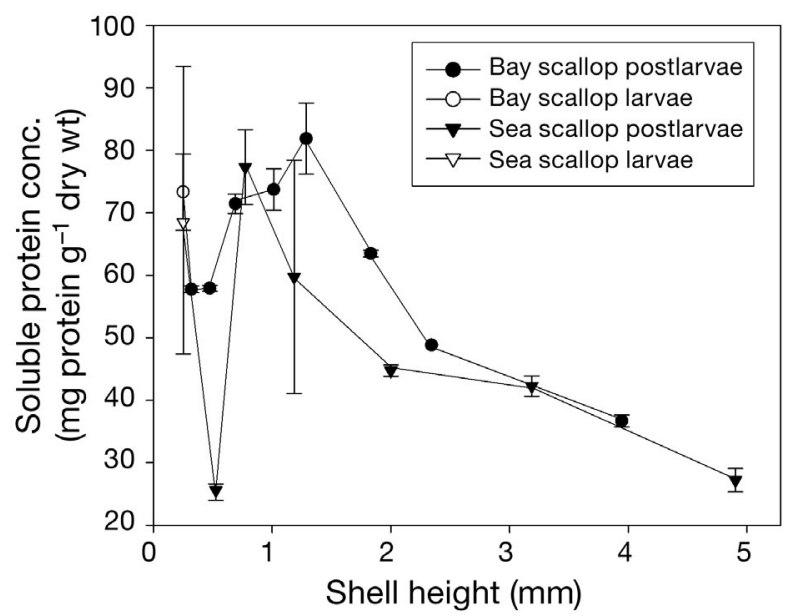

Fig. 2. Argopecten irradians, Placopecten magellanicus. Soluble protein concentrations based on lyophilized weight of samples. Values represent means ( \pm data range); $n=2$ per shell height

cantly reduced between larval and early postlarval stages in both scallop species (Fig. 3). It remained at similar levels between early and late postlarval bay scallops (0.37 and $0.36 \mathrm{U} \mathrm{g}^{-1}$ protein, respectively), but for sea scallops it exhibited a significant increase between early and late postlarval stages $(0.27$ to $0.45 \mathrm{U} \mathrm{g}^{-1}$ protein). The opposite effect was found for the specific activity of protease (azocasein): activity significantly increased between larvae and early postlarvae for both scallop species. It subsequently remained constant in sea scallops, but dropped sig-

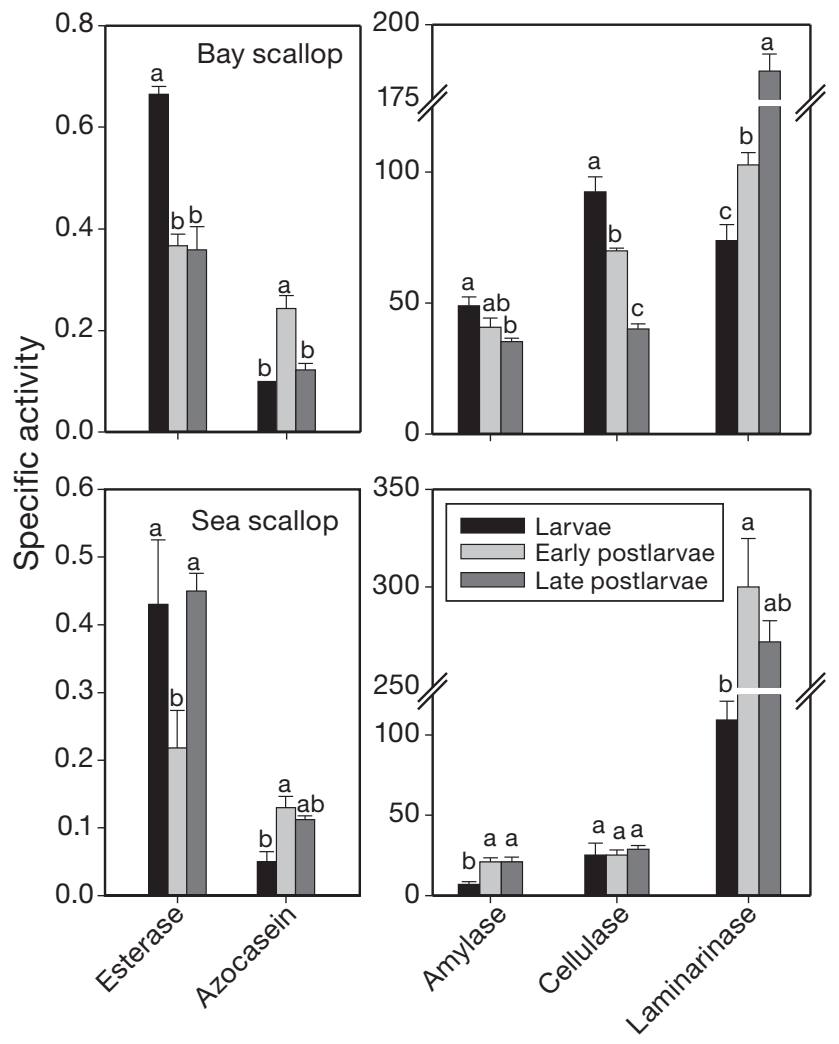

Fig. 3. Argopecten irradians, Placopecten magellanicus. Specific activities of digestive enzymes among 3 discrete morphological stages: (1) larvae, (2) early postlarvae $<1 \mathrm{~mm}$ shell height and (3) late postlarvae $>1 \mathrm{~mm}$ shell height for bay scallops A. irradians (upper panels) and sea scallops P. magellanicus (lower panels). Specific activity was defined as the release of $1 \mu \mathrm{mol}$ of $\mathrm{p}$-nitrophenol $\mathrm{min}^{-1} \mathrm{~g}^{-1}$ protein (esterase), the change in optical density per hour per milligram protein (protease) and the release of $1 \mu \mathrm{mol}$ glucose $\mathrm{min}^{-1} \mathrm{~g}^{-1}$ protein ( $\alpha$-amylase, cellulase, laminarinase). Values represent means $(+\mathrm{SE})$; different letters designate significant differences among developmental stages; 1 -way ANOVA; $p<0.05$. For bay scallops $\mathrm{n}=2,6$ and 9 for larvae, early postlarvae and late postlarvae, respectively; $\mathrm{n}=3,3$ and 8 , respectively, for sea scallops

nificantly between early and late postlarval stages of bay scallops (Fig. 3).

While different patterns in esterase and protease activity were exhibited over development by these 2 species, the ontogenetic changes in the esterase: protease ratio were strikingly similar (Fig. 4). This ratio exhibited a $\sim 5$ - to 7 -fold decrease between larvae and immediate postlarvae in both species, with values of 6.5 to 8.3 decreasing to 1.1 to 1.2 . This was followed by a period of relative increase from sizes of $\sim 320$ to $525 \mu \mathrm{m}$ until scallops attained $\sim 1200 \mu \mathrm{m}$ in $\mathrm{SH}_{i}$ this ratio remained relatively constant thereafter.

Specific activities of the 3 carbohydrases varied over development; the most pronounced changes occurred before scallops attained $\sim 1.0$ to $1.2 \mathrm{~mm} \mathrm{SH}$ 

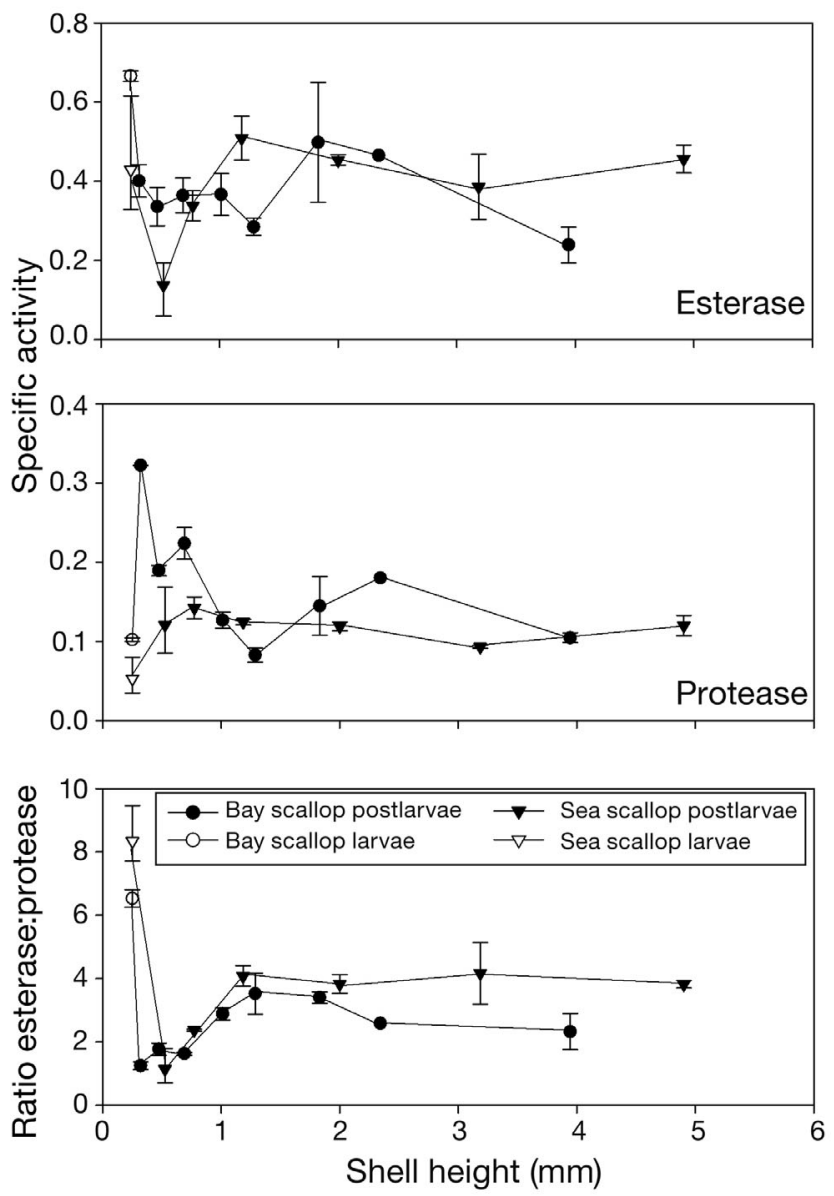

Fig. 4. Argopecten irradians, Placopecten magellanicus. Specific activities (see Fig. 3) of esterase and protease, and the ratio of esterase:protease, over development for bay scallops $A$. irradians and sea scallops $P$. magellanicus. Values represent means ( \pm data range), $\mathrm{n}=2$ tanks for each sampling size

(Fig. 5). In bay scallops, $\alpha$-amylase steadily decreased across the 3 developmental stages (48.9 to $35.3 \mathrm{U} \mathrm{g}^{-1}$ protein), while there was a 3 -fold increase from 7.1 to $22.8 \mathrm{U} \mathrm{g}^{-1}$ protein between larval and early postlarval stages in sea scallops, which remained constant into the late postlarval stage (Fig. 3). A steady and significant decrease in cellulase activities of bay scallops was observed (92.5 to $40.1 \mathrm{U} \mathrm{g}^{-1}$ protein), while this activity remained constant among these 3 developmental stages in sea scallops. Specific activities of laminarinase increased between larval and postlarval stages in both scallop species ranging from 73.9 to $184.4 \mathrm{U} \mathrm{g}^{-1}$ protein in bay scallops and from 109.3 to $308.3 \mathrm{U} \mathrm{g}^{-1}$ protein in sea scallops. Overall, the weight-specific ontogenetic patterns observed for the 3 carbohydrates (data not shown) were comparable to those expressed per gram protein (Figs. 3 \& 5). Regardless of the units used, amylase
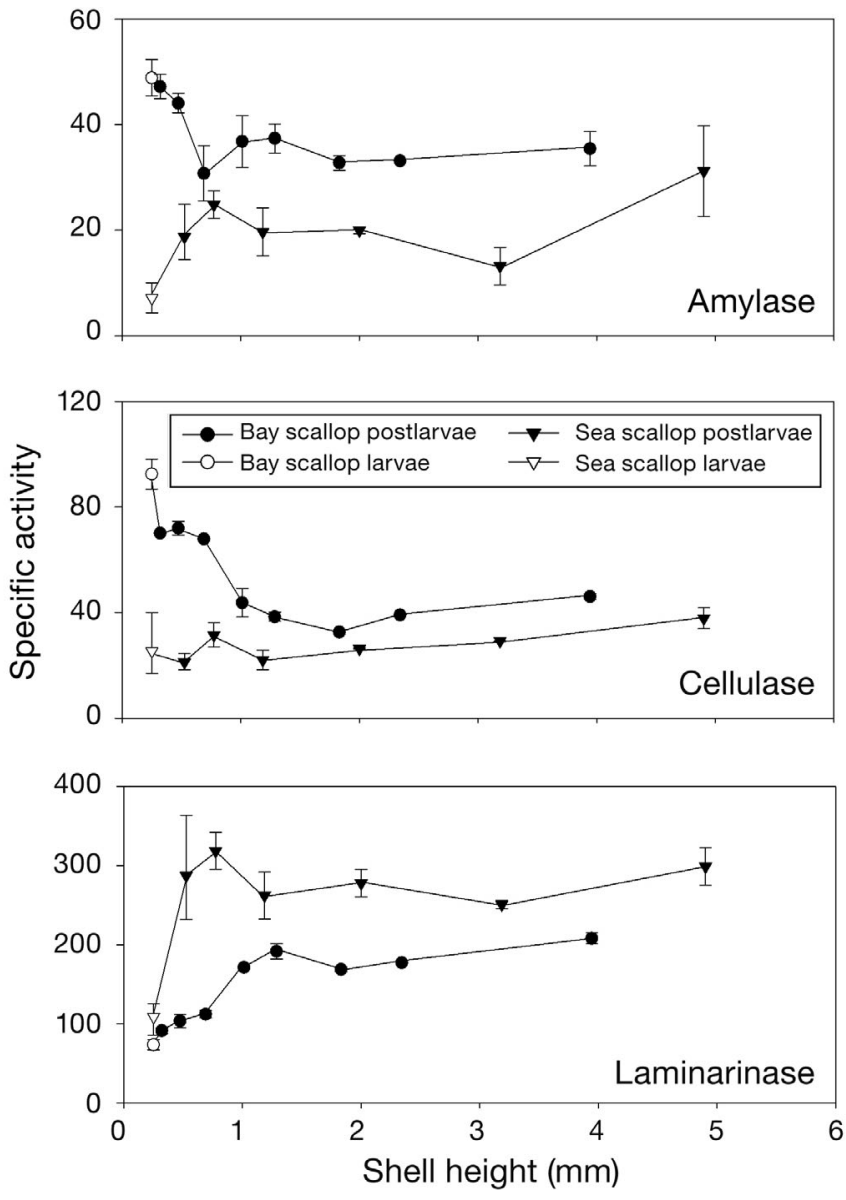

Fig. 5. Argopecten irradians, Placopecten magellanicus. Specific activities (see Fig. 3 ) of the carbohydrases $\alpha$-amylase, cellulase and laminarinase over development in bay scallops $A$. irradians and sea scallops P. magellanicus. Values represent means ( \pm data range), $\mathrm{n}=2$ tanks for each sampling size

and cellulose activities as a function of $\mathrm{SH}$ consistently showed higher activities in bay scallops than in sea scallops, while the reverse was observed for laminarinase.

\section{Comparison of specific activity between species}

A $t$-test failed to detect a difference in specific activities of esterase between species when these were averaged across all developmental sizes tested ( $\mathrm{p}>$ 0.05). However, there was a significant difference in protease activity between species with higher values identified in bay scallops $(p<0.05)$. All 3 carbohydrases showed highly significant differences in activity between the 2 scallop species ( $p<0.001$; Fig. 6 A) . It is noteworthy that bay scallops exhibited specific activities of $\alpha$-amylase and cellulase almost twice 

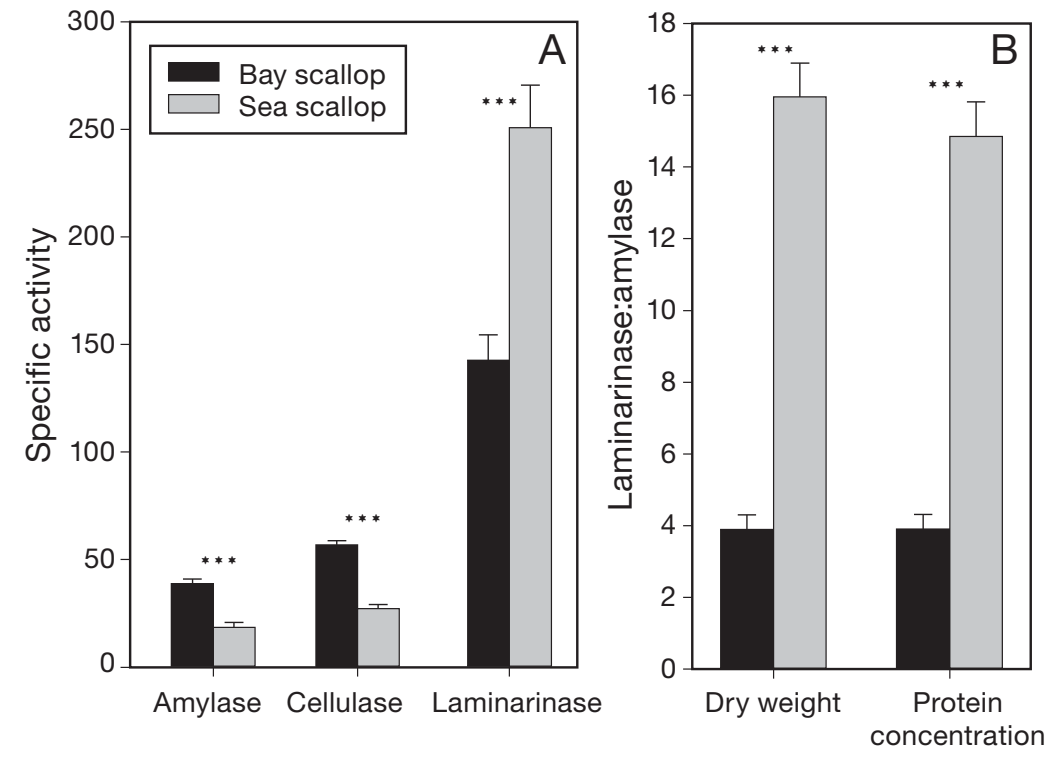

Fig. 6. Argopecten irradians, Placopecten magellanicus. (A) Mean specific activities (see Fig. 3 ) of 3 carbohydrases ( $\alpha$-amylase, cellulase and laminarinase) from whole body homogenates of bay scallops A. irradians and sea scallops $P$. magellanicus. (B) Ratios of laminarinase:amylase activities from whole body homogenates of bay and sea scallops, expressed per dry (lyophilized) weight or per gram soluble protein. Values represent means of all developmental sizes $(+\mathrm{SE}) ; \mathrm{n}=17$ for bay scallops and 16 for sea scallops. Differences between species determined by $t$-test ${ }_{i * *}{ }^{* *}<0.001$

as high (38.8 and $56.8 \mathrm{U} \mathrm{g}^{-1}$ protein) as those determined for sea scallops (18.5 and 27.1 $\mathrm{U} \mathrm{g}^{-1}$ protein), while the mean laminarinase activity of sea scallops was approximately twice as high as that found in bay scallops (Fig. 6A; 250.6 vs. $142.6 \mathrm{U} \mathrm{g}^{-1}$ protein). Laminarinase:amylase ratios were significantly ( 4 -fold) higher in sea scallops than in bay scallops, regardless of whether activity was expressed relative to grams protein or grams freeze-dried tissue mass (Fig. 6B). Similarly, laminarinase:cellulase ratios were $\sim 3$-fold higher than those measured for bay scallops irrespective of the units used (activity per gram protein or per gram freeze-dried tissue mass).

\section{DISCUSSION}

Both scallop species grew exponentially during the experiment, indicating a normal pattern of growth and development. Daily shell growth rates met or exceeded growth rates previously recorded for Argopecten irradians (Lu \& Blake 1996, Milke et al. 2006) and Placopecten magellanicus (Parsons et al. 1993, Milke et al. 2004) of similar size. Variable survival, however, was observed between cohorts of bay scallops. Therefore, examination of digestive enzyme activity among additional cohorts could be of value in establishing the range of possible variation in this parameter over ontogeny.

Different ontogenetic patterns of enzyme activity were observed both among different enzymes tested and between scallop species. It is possible that changes in the specific enzyme activities over development could have been affected by changes in soluble protein content in the samples; however, patterns of enzymatic activity were very similar when plotted on a per protein or per dry weight basis. This was also reflected in the comparable laminarinase:amylase or cellulase ratios obtained using these 2 units. Although we cannot rule out the possibility that lyophilization of samples prior to homogenization may have reduced enzymatic activities, this would only affect our observed ontogenetic patterns in the 2 scallop species if the sample treatment showed species-, enzyme-, or stage-specific effects.

The variable ontogenetic pattern of enzyme activity observed in the present study contrasts with the steady increase in specific activities of $\alpha$-amylase over ontogeny in postlarval prawn, Fennero penaeus indicus (Ribeiro \& Jones 2000) and early stages (gold embryo to intermolt Juvenile Stage V) of the lobster Homarus americanus (Biesiot \& McDowell Capuzzo 1990), which might be expected if digestive capacity is correlated with age and associated morphological and functional changes of feeding organs. The assays measured total activity of each enzyme and may include activities in tissues not related to digestion. However, proteolytic activities in non-digestive tissues are most probably lysosomal-derived cathepsin, which are cysteine proteinases and are not likely to be active under the oxidative assay conditions used (Barrett et al. 1998). There is limited information on the lysosomal contribution to the carbohydrase activities examined in our study.

Sampling times were chosen to encompass major developmental changes in the functional morphology of the feeding organs, especially the gills, in the 2 scallop species (Barré 2001, Veniot et al. 2003), which may also be associated with changes in digestive capacity. Prior to $500 \mu \mathrm{m} \mathrm{SH}$, postlarval bay scallops have a rudimentary gill, with reflection of the 
inner demibranch occurring at $\sim 600 \mu \mathrm{m} \mathrm{SH}$, and a fully formed gill at $3.3 \mathrm{~mm}$ (Barré 2001). Although more protracted, gill development in sea scallops followed a similar progression, with gill reflection occurring around $1 \mathrm{~mm} \mathrm{SH}$ (Veniot et al. 2003). Reflection of the outer gill demibranch in sea and bay scallop postlarvae coincided with a marked increase in the rate of proliferations of gill filaments, suggesting that this may represent a critical transition during development (Barré 2001, Veniot et al. 2003). Additionally, Kingzett (1993) found that there was a sharp increase in particle clearance rate of the scallop Patinopecten yessoensis at $\sim 600 \mu \mathrm{m}$, the size of gill reflection in this species. Changes in enzymatic activity between early and late postlarval stages in the present study may thus correspond with a change in feeding function associated with increased feeding efficiency, in turn linked to major transitions in development of the gill and associated feeding organs. We speculate that gut morphology, as well as digestive enzyme activity, may develop in parallel with the above changes, although this remains to be determined.

Bay and sea scallops exhibited remarkably similar and distinct ontogenetic patterns in the ratio of esterase:protease activity, indicating a shift in the need for lipase activity in pediveliger larvae to protease activity in postlarvae. Lipid reserves, especially triacylglycerols (TAG), are considered essential for the metamorphic success of bivalve larvae (Gallager \& Mann 1986, Gallager et al. 1986), including sea scallops (Pernet et al. 2006). Therefore, high esterase activities prior to and during metamorphosis may facilitate the catabolism of this energy substrate. The high protease activities evidenced by postlarval scallops relative to larvae in the present study may reflect the high protein demand required to maintain rapid postmetamorphic growth. Protein sparing to meet growth demands has been well documented in mussels, Mytilus spp. Thus, conservation of dietary protein for growth is consistent with high oxygen consumption rate/nitrogen excretion rate $(\mathrm{O} / \mathrm{N})$ ratios of juvenile M. trossulus fed a low protein diet (Kreeger \& Langdon 1993), and with the high (75\%) maximum efficiency of protein recycling (defined as the percent of protein breakdown products recycled to protein synthesis) measured in juvenile $M$. edulis (Hawkins et al. 1989). High relative protease activity during postmetamorphic stages in the present study may thus reflect high protein recycling. It cannot be ruled out, however, that it may be associated with the use of protein as an energy substrate, since, in contrast to mussels and oysters that preferentially use glycogen as their energy source (e.g. Gabbott \& Bayne 1973), pectinids rely to a greater degree on protein catabolism to meet energy demands (Epp et al. 1988).

Mean cellulase activity was higher in bay scallops than in sea scallops, which may be required to utilize detrital material frequently encountered in the former's estuarine habitat, as has been described for the ribbed mussel Geukensia demissa (Lucas \& Newell 1984). While it is possible that the higher activities of $\alpha$-amylase and cellulase observed in bay scallops are associated with the higher temperatures to which these animals are adapted and were reared, this is unlikely as the laminarinase activity was approximately twice as high in sea scallops, and a temperature effect would be expected across all enzymes tested. Laminarinase activity has been widely reported across scallop species such as Argopecten irradians (Brock et al. 1986), A. purpuratus (Fernández-Reiriz et al. 2004), Placopecten magellanicus, (Wojtowicz 1972) and Pecten maximus (Stark \& Walker 1983). In the present study an increase in specific activity of laminarinase was observed over development in both species, and a similar increase was reported between $4 \mathrm{~mm}$ and 40 to $50 \mathrm{~mm}$ for $P$. maximus (Økland et al. 2001, Reitan 2011), and during development of post-settlement abalone Haliotis discus hannai offered a diatom-based diet (Takami et al. 1998). While this increase in laminarinase activity could reflect a developmental transition, it could also occur in response to chrysolaminarin, a polysaccharide found in diatoms (Beattie et al. 1961) which can be hydrolyzed by laminarinase (Hassett 1994).

It is unclear to what degree enzymatic activity is induced by the presence of substrate. Enzymatic activity against cellulose and alginate during postlarval development of the abalone Haliotis discus hannai did not require the presence of the corresponding substrate (Takami et al. 1998). Neither acclimation time nor food type had a significant effect on specific carbohydrase activity in adult cockles Cerastoderma edule (Navarro et al. 2009), and no difference in laminarinase activity was observed in juvenile Pecten maximus under starvation or offered different diets (Reitan 2011). However, other work conducted on C. edule has shown a positive correlation between increased organic content of food and the specific activity of cellulase (Ibarrola et al. 1996, 1998) and specific activities of laminarinase decreased during starvation in juvenile venerid clams Ruditapes decussatus and Venerupis pullastra (Albentosa \& Moyano 2008), implying a relationship between food availability and enzymatic activity. While it cannot be ruled out that seasonal variation can influence enzymatic activity, as shown for adult Mytilus trossulus 
(Kreeger 1993), it is unlikely to have resulted in the ontogenetic patterns observed in the current study.

The present study shows that digestive enzyme activity is variable both over early development and between scallop species. These changes might be related to energetic requirements for metamorphosis as well as postlarval growth and development. Further work is necessary to determine if substrate availability induces enzymatic activity in bay and sea scallops, which may, in fact, be species, stage and/or enzyme specific.

Acknowledgements. We thank S. MacQuarrie and S. McKenna (Institute for Marine Biosciences, IMB/NRC) for algal culture and help in maintenance of experiments, $\mathrm{M}$. Goguen for assisting with enzymatic methods development, J. Rose for exchanges concerning statistical analyses, as well as 4 anonymous reviewers. The present study was partially supported by AquaNet, a Natural Sciences and Engineering Research Council (NSERC) Network of Centers of Excellence in Canadian Aquaculture, and by IMB operating funds awarded to V.M.B., and is part of a PhD dissertation by L.M. at Dalhousie University, Department of Biology.

\section{LITERATURE CITED}

- Albentosa M, Moyano FJ (2008) Influence of nutritional stress on digestive enzyme activities in juveniles of two marine clam species, Ruditapes decussatus and Venerupis pullastra. J Sea Res 59:249-258

Albentosa M, Moyano FJ (2009) Differences in the digestive biochemistry between the intertidal clam, Ruditapes decussatus, and the subtidal clam, Venerupis pullastra. Aquacult Int 17:273-282

Barré C (2001) Ontogenèse des organes de l'alimentation et sensoriels chez deux Pectinidés: Placopecten magellanicus (Gmelin, 1791) et Argopecten irradians (Lamarck, 1819). Diplôme d'études supérieurs, Université Paris

Barrett AJ, Rawlings ND, Woessner JF (1998) Introduction: cysteine peptidases and their clans. In: Barrett AJ, Rawlings ND, Woessner JF (eds) Handbook of proteolytic enzymes. Academic Press, London, p 545

Beattie A, Hirst EL, Percival E (1961) Studies on the metabolism of the Chrysophyceae. Comparative structural investigations on leucosin (chrysolaminarin) separated from diatoms and laminarin from the brown algae. Biochem J 79:531-537

Beninger PG, Dwiono SAP, Le Pennec M (1994) Early development of the gill and implications for feeding in Pecten maximus (Bivalvia: Pectinidae). Mar Biol 119:405-412

Biesiot PM, McDowell Capuzzo J (1990) Changes in digestive enzyme activities during early development of the American lobster Homarus americanus Milne Edwards. J Exp Mar Biol Ecol 136:107-122

Brock V, Kennedy VS, Brock A (1986) Temperature dependency of carbohydrase activity in the hepatopancreas of thirteen estuarine and coastal bivalve species from the North American east coast. J Exp Mar Biol Ecol 103: 87-101

Chaparro OR, Videla JA, Thompson RJ (2001) Gill morphogenesis in the oyster Ostrea chilensis. Mar Biol 138: 199-207
Charney J, Tomarelli RM (1947) A colorimetric method for the determination of the proteolytic activity of duodenal juice. J Biol Chem 171:501-505

Couturier C, Dabinett P, Lanteigne M (1995) Scallop culture in Atlantic Canada. In: Boghen AD (ed) Cold water aquaculture in Atlantic Canada. The Tribune Press Ltd., Sackville, NB, p 297-340

Dadswell MJ, Parsons GJ (1991) Potential for aquaculture of sea scallop, Placopecten magellanicus (Gmelin, 1791) in the Canadian Maritimes using naturally collected spat. In: Shumway SE, Sandifer PA (eds) An international compendium of scallop biology and culture. World Aquaculture Society, Baton Rouge, LA, p 300-307

Epp J, Bricelj VM, Malouf RE (1988) Seasonal partitioning and utilization of energy reserves in two age classes of the bay scallop Argopecten irradians irradians (Lamarck). J Exp Mar Biol Ecol 121:113-136

Fernández-Reiriz MJ, Labarta U, Navarro JM (2004) Feeding and digestive response of Argopecten purpuratus to short-term variation in food quality and quantity. Aquaculture 237:347-364

Fernández-Reiriz MJ, Navarro JM, Labarta U (2005) Enzymatic and feeding behaviour of Argopecten purpuratus under variation in salinity and food supply. Comp Biochem Physiol A Mol Integr Physiol 141:153-163

Gabbott PA, Bayne BL (1973) Biochemical effects of temperature and nutritive stress on Mytilus edulis L. J Mar Biol Assoc UK 53:269-286

Gallager SM, Mann R (1986) Growth and survival of larvae of Mercenaria mercenaria (L.) and Crassostrea virginica (Gmelin) relative to broodstock conditioning and lipid content of eggs. Aquaculture 56:105-121

Gallager SM, Mann R, Sasaki GC (1986) Lipid as an index of growth and viability in three species of bivalve larvae. Aquaculture 56:81-103

Gawlicka A, Parent B, Horn MH, Ross N, Opstad I, Torrissen OJ (2000) Activity of digestive enzymes in yolk-sac larvae of Atlantic halibut (Hippoglossus hippoglossus): indication of readiness for first feeding. Aquaculture 184: 303-314

Guillard RRL (1975) Culture of phytoplankton for feeding marine invertebrates. In: Smith WL, Chanley MH (eds) Culture of marine invertebrate animals. Plenum Publishing Company, New York, NY, p 29-60

> Hassett RP (1994) Digestive enzyme activity is present in mature copepods despite the absence of the corresponding substrates in the diet during development. J Plankton Res 16:413-420

Hawkins AJS, Widdows J, Bayne BL (1989) The relevance of whole-body protein metabolism to measured costs of maintenance and growth in Mytilus edulis. Physiol Zool 62:745-763

Hoehne-Reitan K, Økland SN, Reitan KI (2007) Neutral lipase and phospholipase activities in scallop juveniles (Pecten maximus) and dietary algae. Aquacult Nutr 13:45-49

Huggins C, Lapides J (1947) Chromogenic substrates. IV. Acyl esters of p-nitrophenol as substrates for the colorimetric determination of esterase. J Biol Chem 170:467-482

> Ibarrola I, Iglesias JIP, Navarro E (1996) Differential absorption of biochemical components in the diet of the cockle Cerastoderma edule: enzymatic responses to variations in seston composition. Can J Zool 74:1887-1897

> Ibarrola I, Navarro E, Iglesias JIP (1998) Short-term adaptation of digestive processes in the cockle Cerastoderma edule exposed to different food quantity and quality. J Comp Physiol B 168:32-40

> Jun-sheng L, Jian-lin L, Ting-ting W (2006) Ontogeny of pro- 
tease, amylase and lipase in the alimentary tract of hybrid juvenile tilapia (Oreochromis niloticus $\times$ Oreochromis aureus). Fish Physiol Biochem 32:295-303

Kamarudin MS, Jones DA, le Vay L, Abidin AZ (1994) Ontogenetic change in digestive enzyme activity during larval development of Macrobrachium rosenbergii. Aquaculture 123:323-333

Kennedy VS (1996) Biology of larvae and spat. In: Kennedy VS, Newell RIE, Eble AF (eds) The eastern oyster Crassostrea virginica. Maryland Sea Grant College, College Park, MD, p 371-421

Kingzett BC (1993) Ontogeny of suspension feeding in postmetamorphic Japanese scallops, Patinopecten yessoensis (Jay). MSc, Simon Fraser University, Vancouver, BC

Kreeger DA (1993) Seasonal patterns in utilization of dietary protein by the mussel Mytilus trossulus. Mar Ecol Prog Ser 95:215-232

Kreeger DA, Langdon CJ (1993) Effect of dietary protein content on growth of juvenile mussels, Mytilus trossulus (Gould, 1850). Biol Bull 185:123-139

Le Chevalier P, Sellos D, Van Wormhoudt A (1995) Purification and partial characterization of chymotrypsin-like proteases from the digestive gland of the scallop Pecten maximus. Comp Biochem Physiol B 110:777-787

> Lever M (1977) Carbohydrate determination with 4-hydroxybenzoic acid hydrazine (PAHBAH): effect of bismuth on the reaction. Anal Biochem 81:21-27

Lever M, Powell JC, Killip M, Small CW (1973) A comparison of 4-hydroxybenzoic acid hydrazide (PAHBAH) with other reagents for the determination of glucose. J Lab Clin Med 82:649-655

- Lowry OH, Rosebrough NJ, Farr AL, Randall RJ (1951) Protein measurement with the folin phenol reagent. J Biol Chem 193:265-275

Lu YT, Blake NJ (1996) Optimum concentrations of Isochrysis galbana for growth of larval and juvenile bay scallops, Argopecten irradians concentricus (Say). J Shellfish Res 15:635-643

Lucas MI, Newell RC (1984) Utilization of saltmarsh grass detritus by two estuarine bivalves: carbohydrase activity of crystalline style enzymes of the oyster Crassostrea virginica (Gmelin) and the mussel Geukensia demissa (Dillwyn). Mar Biol Lett 5:275-290

Luna-González A, Maeda-Martínez AN, Ascencio-Valle F, Robles-Mungaray M (2004) Ontogenetic variations of hydrolytic enzymes in the Pacific oyster Crassostrea gigas. Fish Shellfish Immunol 16:287-294

Milke LM, Bricelj VM, Parrish CC (2004) Growth of postlarval sea scallops, Placopecten magellanicus, on microalgal diets, with emphasis on the nutritional role of lipids and fatty acids. Aquaculture 234:293-317

Milke LM, Bricelj VM, Parrish CC (2006) Comparison of early life stages of the bay scallop, Argopecten irradians: effects of microalgal diets on scallop growth and biochemical composition. Aquaculture 260:272-289

Milke LM, Bricelj VM, Parrish CC (2008) Biochemical characterization and nutritional value of three Pavlova spp. in unialgal and mixed diets with Chaetoceros muelleri for postlarval sea scallops, Placopecten magellanicus. Aquaculture 276:130-142

Naidu KS (1991) Sea scallop, Placopecten magellanicus. In: Shumway SE (ed) Scallops: biology, ecology and aquaculture. Elsevier, New York, NY, p 861-898

Navarro E, Méndez S, Ibarrola I, Urrutia MB (2009) Compar-

Editorial responsibility: Peter Beninger,

Nantes, France ative utilization of phytoplankton and vascular plant detritus by the cockle Cerastoderma edule: digestive responses during diet acclimation. Aquat Biol 6:247-262

Økland SN, Reitan KH, Reitan KI (2001) Lipid and carbohydrate digestion in scallop (Pecten maximus) juveniles. In: Hendry CI, Stappen GV, Wille M, Sorgeloos P (eds) Larvi'01: Fish and Shellfish Larviculture Symposium. European Aquaculture Society, Ostende, p 445-448

$>$ Parsons GJ, Robinson SMC, Roff JC, Dadswell MJ (1993) Daily growth rates as indicated by valve ridges in postlarval giant scallop (Placopecten magellanicus) (Bivalvia: Pectinidae). Can J Fish Aquat Sci 50:456-464

> Pérez-Casanova JC, Murray HM, Gallant JW, Ross NW, Douglas SE, Johnson SC (2004) Bile salt-activated lipase expression during larval development in the haddock (Melanogrammus aeglefinus). Aquaculture 235:601-617

> Pernet F, Bricelj VM, Cartier S (2006) Lipid class dynamics during larval ontogeny of sea scallops, Placopecten magellanicus, in relation to metamorphic success and response to antibiotics. J Exp Mar Biol Ecol 329:265-280

Pörtner HO (2002) Climate variations and the physiological basis of temperature dependent biogeography: systemic to molecular hierarchy of thermal tolerance in animals. Comp Biochem Physiol A Mol Integr Physiol 132: $739-761$

Reitan KI (2011) Digestion of lipids and carbohydrates from microalgae (Chaetoceros muelleri Lemmermann and Isochrysis aff. galbana clone T-ISO) in juvenile scallops (Pecten maximus L.). Aquacult Res 42:1530-1538

Rhodes EW, Widman JC (1980) Some aspects of the controlled production of the bay scallop (Argopecten irradians). Proc World Maricult Soc 11:235-246

Ribeiro FALT, Jones DA (2000) Growth and ontogenetic change in activities of digestive enzymes in Fennero penaeus indicus postlarvae. Aquacult Nutr 6:53-64

Ross NW, Firth KJ, Wang A, Burka JF, Johnson SC (2000) Changes in hydrolytic enzyme activities of naive Atlantic salmon Salmo salar skin mucus due to infection with the salmon louse Lepeophtheirus salmonis and cortisol implantation. Dis Aquat Org 41:43-51

Samain JF, Daniel JY, LeCoz JR, Michaud F, Moal J (1995) Digestive enzymes during development of Pecten maximus larvae. IFREMER Actes Colloq, p 265 (abstract)

Sastry AN (1965) The development and external morphology of pelagic larval and post-larval stages of the bay scallop, Aequipecten irradians concentricus Say, reared in the laboratory. Bull Mar Sci 15:417-435

Stark JR, Walker RS (1983) Carbohydrate digestion in Pecten maximus. Comp Biochem Physiol 76B:173-177

Takami H, Kawamura T, Yamashita Y (1998) Development of polysaccharide degradation activity in postlarval abalone Haliotis discus hannai. J Shellfish Res 17:723-727

Uriarte I, Farías A (1999) The effect of dietary protein content on growth and biochemical composition of Chilean scallop Argopecten purpuratus (L.) postlarvae and spat. Aquaculture 180:119-127

Veniot A, Bricelj VM, Beninger PG (2003) Ontogenetic changes in gill morphology and significance for food acquisition in the scallop, Placopecten magellanicus. Mar Biol 142:123-131, and Erratum 142:827-832

- Wojtowicz MB (1972) Carbohydrases of the digestive gland and the crystalline style of the Atlantic deep-sea scallop (Placopecten magellanicus, Gmelin). Comp Biochem Physiol A Comp Physiol 43:131-141

Submitted: February 21, 2011; Accepted: November 30, 2011 Proofs received from author(s): January 10, 2012 